\title{
Evaluasi Penerapan Program Lumbung Pangan Masyarakat di Subak Seronggo Desa Pangkungkarung Kecamatan Kerambitan Kabupaten Tabanan
}

\author{
I GEDE DAKSA WISMAYA, I NYOMAN SUTJIPTA, \\ WAYAN SUDARTA
}

Program Studi Agribisnis, Fakultas Pertanian, Universitas Udayana

J1. PB. Sudirman Denpasar 80323

E-mail: daksawismaya23@gmail.com

nsutjipta@yahoo.com

\author{
Abstract \\ Implementation Evaluation of food Barn Communities Program \\ in Subak Seronggo, Pangkungkarung Village, Sub District Kerambitan, \\ Tabanan Regency
}

The economic crisis in 1998 has affected the national food security in household sphere. Food security is the strength of a nation to maintain the stability of national food and thus, the government established a program focuses on maintaining the stability of national food security using food barn communities program. Each program developed by the government needs someone to evaluate it so there will be indicator of the program success. The purpose of the research is finding out the food barn program evaluation in Subak Seronggo. This research was conducted in Subak Seronggo, Pangkungkarung Village, Sub District Kerambitan, Tabanan Regency. The population of Subak Seronggo is 100 people. The determination of samples uses simple random sampling. Respondent were drawn by 50 people. The result is showed on the growth phase that the government gives the requirement used to run the food barns program. The development phase can be categorized as a good achievement with score $(3,71)$, the autonomy phase can be categorized in medium level of achievements with score $(3,33)$. The result is in good level of achievements with score $(3,98)$. Based on the result, the food mow in the Subak Seronggo is categorized as good, it is because the members manage and utilize the aid using the agreement that formed according to the group deals so that the social discrepancy in the group can be avoided.

Keywords: endurance of food, food barn, evaluation program

\section{Pendahuluan}

\subsection{Latar Belakang}

Krisis ekonomi yang melanda Indonesia sejak tahun 1998 sampai saat ini telah berdampak pada menurunnya kualitas ketahanan pangan masyarakat, khususnya pada tingkat rumah tangga (Jayawinata, 2015). Ini yang menyebabkan ketahanan 
pangan nasional masih merupakan isu yang strategis bagi Indonesia mengingat kecukupan produksi, distribusi, dan konsumsi pangan memiliki dimensi yang terkait dengan dimensi sosial, ekonomi, dan politik. Ketahanan pangan merupakan tantangan yang mendapatkan prioritas untuk mencapai kesejahteraan bangsa pada abad millennium ini (Arifin, 2005).

Terwujudnya ketahanan pangan merupakan sinergi dari interaksi ketiga subsistem tersebut. Subsitem ketersediaan pangan mencakup aspek produksi, cadangan serta keseimbangan antara ekspor dan impor pangan. Ketersediaan pangan harus dikelola sedemikian rupa sehingga walaupun produksi pangan bersifat musiman, terbatas dan tersebar antar wilayah, tetapi volume pangan yang tersedia bagi masyarakat harus cukup jumlah dan jenisnya serta stabil penyediaannya dari waktu ke waktu. Oleh sebab itu, Masyarakat mempunyai hak dan kesempatan seluas -luasnya dalam upaya mewujudkan cadangan pangan masyarakat yang dilakukan secara mandiri seta sesuai kemampuan masing - masing (Juklak BPMPD Tahun 2014).

Cadangan pangan nasional terdiri dari cadangan pangan pemerintah, cadangan pangan pemerintah daerah, dan cadangan pangan masyarakat. Kelembagaan lumbung pangan desa yang masih pada tingkatan sederhana dan berorientasi sosial, mempunyai potensi untuk dikembangkan dan direvitalisasi melalui proses pemberdayaan secara sistematis, terpadu dan berkesinambungan dengan melibatkan seluruh unsur terkait. Upaya ini diharapkan akan mampu memberikan kontribusi yang signifikan terhadap perwujudan ketahanan pangan, sehingga lembaga sosial ekonomi masyarakat ini mampu menjadi lembaga penggerak ekonomi perdesaan.

Subak Seronggo adalah subak yang berlokasi di Desa Pangkungkarung, Kecamatan Kerambitan, Kabupaten Tabanan. Subak Seronggo memiliki jumlah anggota sebanyak 300 orang dan luas lahan yang terdapat di Subak Seronggo sekitar 110 Ha. Subak Seronggo termasuk Subak yang mendapatkan DAK (Dana Alokasi Khusus) yang bertujuan untuk membentuk Lumbung Pangan Masyarakat. Lumbung Pangan Masyarakat di Subak Seronggo berdiri pada tahun 2014 dan beranggotakan sebanyak 100 orang. Dilihat dari uraian di atas penulis tertarik untuk melakukan penelitian lebih lanjut mengenai evaluasi penerapan program lumbung pangan yang terjadi di Subak Seronggo, untuk itu pada penelitian ini penulis mengambil judul "Evaluasi Penerapan Program Pengembangan Lumbung Pangan Masyarakat di Subak Seronggo Desa Pangkungkarung Kecamatan Kerambitan Kabupaten Tabanan Bali”.

\subsection{Rumusan Masalah}

Berdasarkan latar belakang tersebut maka dapat dirumuskan masalah sebagai berikut.

1. Bagaimana penerapan program lumbung pangan masyarakat di Subak Seronggo dan sejauh mana program tersebut sudah terlaksana?

2. Bagaimana hasil penerapan program lumbung pangan masyarakat di Subak Seronggo? 


\subsection{Tujuan Penelitian}

Berdasarkan rumusan masalah, maka tujuan penelitian ini adalah untuk mengetahui hal-hal sebagai berikut.

1. Penerapan program lumbung pangan masyarakat di Subak Seronggo dan sejauh mana program tersebut sudah terlaksana.

2. Hasil penerapan program lumbung pangan masyarakat Subak Seronggo.

\section{Metode Penelitian}

\subsection{Lokasi dan Waktu Penelitian}

Lokasi penelitian ini dilaksanakan di Subak Seronggo, Desa Pangkungkarung, Kecamatan Kerambitan, Kabupaten Tabanan. Penelitian ini ditentukan secara purposive yaitu penelitian yang dilakukan secara sengaja dan terencana (Singarimbun dan Efendi, 1989). Waktu penelitian dari Mei sampai dengan Agustus 2016. Adapun pertimbangan pemilihan lokasi penelitian karena Subak Seronggo sebagai subak penerima bantuan lumbung pangan masyarakat pada tahun 2014 .

\subsection{Sumber dan Jenis Data}

Sumber data dalam penelitian ini meliputi data primer dan data sekunder. Jenis data terdiri atas data kualitatif dan data kuantitatif. Data primer adalah data yang langsung dan segera diperoleh dari sumber data oleh penyelidik (Surakhmad, 1994). Sumber diperoleh dari hasil wawancara dengan pengelola kelompok lumbung pangan masyarakat. Data sekunder diperoleh dari dokumen-dokumen Badan Pemberdayaan Masyarakat dan Pemerintahan Desa, dan referensi berupa buku, jurnal, skripsi, makalah serta data lain yang berkaitan dengan permasalahan, dan informasi dokumentasi lain yang dapat diambil melalui sistem Online mengenai konsep lumbung pangan itu sendiri. Data kualitatif menjelaskan mengenai evaluasi penerapan program lumbung pangan masyarakat di Subak Seronggo, dan semua informasi mengenai lumbung pangan di Subak Seronggo. Data kuantitatif berupa hasil rekapitulasi data skor dan skala lima.

\subsection{Populasi dan Sampel (Responden)}

Populasi dalam penelitian ini seluruh petani aktif di Subak Seronggo yang berjumlah 100 orang petani. Penetapan pengambilan responden menggunakan metode simple random sampling, dilakukan dengan persentase $10 \%$ mewakili respresentatif populasi aktif sebesar 100 orang, sehingga total responden menjadi 50 orang petani. Sevilla (1993) menyatakan semakin kecil toleransi kesalahan, semakin akurat sampel menggambarkan populasi.

\subsection{Pengumpulan Data}

Pengumpulan data dalam penelitian ini melalui wawancara, wawancara mendalam, observasi, dan pencatatan. Wawancara merupakan metode pengumpulan 
informasi dengan bertanya langsung kepada pihak yang terkait sehingga diperoleh data kualitatif, kuantitatif maupun keduanya (Wibisono, 2013) dilakukan kepada pekaseh di Subak Seronggo. Wawancara mendalam dilakukan kepada petugas di BPMPD selaku pemberi bantuan, sedangkan observasi dilakukan dengan melakukan pengamatan langsung ke lokasi Subak Seronggo. Pencatatan dilakukan dari hasil observasi.

\subsection{Variabel, Indikator, Parameter, dan Pengukuran}

Variabel merupakan gejala yang menjadi fokus peneliti untuk diamati (Sugiyono, 2010) penelitian ini untuk mengetahui evaluasi penerapan program lumbung pangan masyarakat di Subak Seronggo. Indikator dalam penelitian ini pelaksanaan program lumbung pangan masyarakat. Parameter pada penelitian ini dibagi menjadi empat yaitu tahap penumbuhan diukur dengan deskriptif kualitatif, tahap pengembangan, tahap kemandirian, dan hasil program diukur menggunakan skor dan skala lima.

\subsection{Analisis Data}

Dikemukakan oleh Sugiyono (2010), analisis data merupakan proses mencari dan menyusun secara sistematis data yang diperoleh dari hasil wawancara, catatan lapangan, dan dokumentasi. Penelitian ini akan dianalisis dengan menggunakan metode analisis deskriptif kualitatif, diperoleh dari hasil penelitian berupa data kualitatif dan kuantitatif akan disajikan dalam bentuk narasi dan tabel yang disusun secara sistematis, dan efisien. Distribusi interval kelas kategori perilaku dalam hasil persentase skor sebagai berikut. Interval kelas (1) 1 s.d 1,8 sangat tidak baik, (2) >1,8 s.d 2,6 tidak baik, (3) >2,6 s.d 3,4 sedang, (4) >3,4 s.d 4,2 baik dan (5) >4,2 s.d 5 sangat baik.

\section{Hasil dan Pembahasan}

\subsection{Tahap Penumbuhan}

Pada tahap penumbuhan ini para pemerintah atau stakeholder bertugas untuk menyalurkan bantuan dan menyusun persyaratan yang akan digunakan sebagai acuan suatu kelompok dalam memenuhi syarat yang diperlukan agar mendapat bantuan sosial lumbung pangan. Syarat yang diberikan pemerintah untuk calon kelompok penerima bansos antara lain; (1) Identifikasi lokasi dan kelompok, (2) Sosialisasi, (3) Seleksi, (4) Penetapan, (5) Pemanfaatan DAK bidang pertanian untuk pembangunan fisik lumbung, dan (6) Inventarisasi.

\subsection{Tahap Pengembangan}

Hasil penelitian evaluasi pada tahap pengembangan Lumbung Pangan Masyarakat di Subak Seronggo diperoleh bahwa tahap pengembangan yang diterima responden terhadap program Lumbung Pangan Masyarakat termasuk dalam kategori 
baik dengan pencapaian skor adalah 3,71. Berikut data hasil penelitian terhadap evaluasi tahap pengembangan akan dirincikan pada Tabel 1.

Tabel 1.

Evaluasi tahap pengembangan pada program Lumbung Pangan Masyarakat di Subak Seronggo, Tahun 2016

\begin{tabular}{lcc}
\hline \multicolumn{1}{c}{ Tahap Pengembangan } & & \\
\hline Parameter & $\begin{array}{c}\text { Jumlah Skor } \\
\text { Rata-rata }\end{array}$ & Kategori \\
\hline $\begin{array}{l}\text { Verifikasi kelompok lumbung pangan masyarakat dan } \\
\text { Penetapan kelompok lumbung pangan masyarakat }\end{array}$ & 4,25 & Sangat baik \\
$\begin{array}{l}\text { Sosialisasi kegaitan lumbung pangan masyarakat dan } \\
\text { Pelatihan kelompok lumbung pangan masyarakat }\end{array}$ & 3,05 & Sedang \\
$\begin{array}{l}\text { Penyusunan Rencana Usaha Kelompok (RUK) } \\
\begin{array}{l}\text { Penyaluran dana bansos ke kelompok lumbung pangan } \\
\text { masyarakat }\end{array}\end{array}$ & 3,46 & Baik \\
$\begin{array}{l}\text { Pengisian cadangan pangan di gudang lumbung } \\
\text { pangan }\end{array}$ & 3,99 & Baik \\
$\begin{array}{l}\text { Penguatan kelembagaan kelompok lumbung pangan } \\
\text { dan Penguatan cadangan pangan kelompok }\end{array}$ & 3,66 & Baik \\
\hline$\quad$ Jumlah & 3,84 & Baik \\
\hline
\end{tabular}

Berdasarkan Tabel 1. pencapaian skor tertinggi dalam parameter evaluasi tahap pengembangan pada kelompok Lumbung Pangan Masyarakat adalah verifikasi dan penetapan kelompok lumbung pangan masyarakat yang masuk dalam kategori sangat baik dan mencapai skor 4,25. Berdasarkan hasil wawancara, pencapaian skor yang diperoleh pada verifikasi dan penetapan kelompok karena pemerintah menyampaikan dan menurut para petani program yang diberikan sangat bermanfaat bagi petani yang berada di subak seronggo. Proses verifikasi yang diberikan oleh pemerintah dianggap oleh para petani tidak rumit sehingga para petani dengan mudah melengkapi berkasberkas yang diperlukan guna melengkapi persyaratan yang diberikan oleh pemerintah kepada para petani. Skor terendah pada indikator evaluasi tahap pengembangan terjadi pada sosialisasi dan pelatihan kelompok yang mencapai kategori skor sedang 3,05. Responden pada parameter ini memberi penilaian cukup beragam sehingga kesenjangan pada skor terlihat. Berdasarkan wawancara, responden cenderung enggan dalam sosialisasi dan pelatihan yang diberikan oleh pemerintah karena para anggota kelompok beranggapan bahwa narasumber yang memaparkan materi sosialisasi dan pelatihan hanya menjelaskan secara biasa saja tanpa menjelaskan 
secara lebih terinci sehingga para aggota agak kesulitan untuk menerima materi yang diberikan. Hasil penelitian diatas menyimpulkan bahwa masih ada ketergantungan responden terhadap kehadiran penyuluh, hal ini seperti yang dikemukakan Suhardiyono (dalam Revikasari, 2010) yaitu, penyuluhan merupakan pendidikan non formal bagi petani beserta keluarganya dimana kegiatan dalam alih pengetahuan dan ketrampilan dari penyuluh lapangan kepada petani dan keluarganya berlangsung melalui proses belajar mengajar.

Tahap pengembangan dengan parameter penyusunan rencana usaha kelompok mencapai jumlah rata-rata skor 3,46 dan tergolong dalam kategori baik. Perolehan skor dengan kategori baik karena para petani anggota kelompok program Lumbung Pangan Masyarakat kompak dalam merumuskan dan merencanakan rencana usaha kelompok. Hal ini dilakukan ketika adanya rapat yang diselenggarakan setiap 1 kali masa panen. Tahap pengembangan dengan parameter pengisian cadangan pangan pada kegiatan program Lumbung Pangan Masyarakat tergolong dalam kategori baik dengan pencapaian rata-rata skor 3,99. Pengisian cadangan pangan merupakan tujuan agar ketersediaan cadangan pangan pada kelompok lumbung pangan masyarakat tetap terjaga dan jika sewaktu-waktu terdapat musim paceklik dapat digunakan sebagaimana mestinya. Pencapaian skor ini diperoleh karena petani telah mengisi cadangan pangan di dalam lumbung pangan sesuai arahan yang diberikan oleh pemerintah, kelompok memilih pengurus yang bertugas untuk mengisi gudang agar pencatatan jumlah cadangan pangan yang terdapat pada lumbung tidak terjadi kesalahan.

Tahap pengembangan dengan parameter penguatan kelembagaan dan penguatan cadangan lumbung pangan pada kegiatan program Lumbung Pangan Masyarakat termasuk dalam kategori baik dengan jumlah skor rata-rata 3,84. Penguatan kelembagaan dan cadangan lumbung pangan merupakan suatu upaya agar program Lumbung Pangan Masyarakat dapat berjalan dan berkembang dengan baik sehingga ketahanan pangan yang diharapkan pemerintah dari adanya program ini dapat tercapai dengan bagimana mestinya.

\subsection{Tahap Kemandirian}

Berikut ini data hasil penelitian terhadap evaluasi tahap kemandirian akan dirincikan pada Tabel 2. Berdasarkan Tabel 2, pencapaian skor tertinggi dalam parameter tahap kemandirian pada kelompok Lumbung Pangan Masyarakat adalah penyaluran dana bansos untuk penguatan modal yang masuk dalam kategori sangat baik dan mencapai skor dengan jumlah rata-rata skor sebanyak 4,3. 
Tabel 2.

Evaluasi Tahap Kemandirian pada Program Lumbung Pangan Masyarakat di Subak Seronggo, Tahun 2016

\begin{tabular}{|c|c|c|}
\hline \multicolumn{3}{|c|}{ Tahap kemandirian } \\
\hline Parameter & $\begin{array}{c}\text { Jumlah Skor } \\
\text { Rata-rata }\end{array}$ & Kategori \\
\hline Penyaluran dana bansos untuk penguatan modal & 4,3 & Sangat baik \\
\hline Pemantapan kelembagaan lumbung pangan & 3,7 & Baik \\
\hline Pemantapan cadangan pangan & 3,27 & Baik \\
\hline $\begin{array}{l}\text { Pelatihan dalam rangka menunjang } \\
\text { keberlanjutan }\end{array}$ & 2,48 & Buruk \\
\hline Pendampingan & 2,16 & Buruk \\
\hline Jumlah & 3,31 & sedang \\
\hline
\end{tabular}

Berdasarkan Tabel 2. parameter pemantapan kelembagaan lumbung pangan menunjukkan rata-rata skor 3,7 ini menunjukkan para responden menganggap bahwa pemantapan kelembagaan lumbung pangan yang dilakukan oleh pengurus kelompok sudah dapat dikatakan baik walaupun terdapat beberapa responden yang menilai masih kurang terhadap pemantapan kelembagaan lumbung pangan ini. Parameter pemantapan cadangan pangan masuk dalam kategori baik dengan pencapaian skor rata-rata sebanyak 3,27, skor didapat karena para anggota sudah merasakan hasil yang diperoleh dari adanya pemantapan cadangan pangan ini karena jika sewaktu waktu anggota membutuhkan uang untuk keperluan mendadak maka cadangan pangan yang dimiliki dalam lumbung pangan dapat dijual kepada pengurus kelompok, akan tetapi terdapat kendala yang mengganggu pemantapan cadangan pangan di Subak Seronggo seperti, keadaan benih yang rusak saat dipanen, padi yang berjamur akibat penjemuran yang kurang baik, dan cuaca yang mempengaruhi hasil panen para anggota kelompok.

Pada parameter pelatihan dalam rangka menunjang keberlanjutan dan pendampingan sama-sama masuk dalam kategori buruk dengan pencapaian skor masing-masing 2,48 dan 2,16, hal ini menunjukkan bahwa masih terdapat kekurangan yang terjadi pada pelatihan dan pendampingan kelompok lumbung pangan msayarakat. Para anggota mengatakan bahwa setelah program diberikan dan pelatihan awal selesai, pemerintah seperti membiarkan program tersebut tanpa adanya penijauan lokasi dan pendampingan intensif sehingga para anggota memberikan penilaian buruk terhadap kedua parameter ini, akan tetapi ada beberapa 
anggota yang mengatakan pihak pemerintah datang akan tetapi hanya sekedar melihat keadaan lumbung pangan saja.

\subsection{Hasil Program Lumbung Pangan}

Indikator hasil program lumbung pangan masyarakat menganalisa hasil yang diperoleh dari dilaksanakannya program lumbung pangan masyarakat ini, pada indikator hasil program lumbung pangan dibagi dalam beberapa poin, yang pertama tersedianya cadangan pangan kelompok, berkembangnya cadangan pangan kelompok secara berkelanjutan, meningkatnya kemampuan kelompok mengelola lumbung pangan, dan kelompok mampu menyusun laporan pertanggung jawaban program. Hasil program lumbung pangan masyarakat yang diterima responden termasuk dalam kategori baik, kategori baik diperoleh dengan pencapaian skor sebesar 3,98.

Jumlah pencapaian skor dengan kategori baik menunjukkan persepsi responden terhadap hasil program lumbung pangan masyarakat dirasa sudah baik dan bermanfaat bagi anggota kelompok. Persentase pencapaian skor tertinggi pada indikator hasil program lumbung pangan masyarakat terjadi pada parameter berkembangnya cadangan pangan kelompok secara berkelanjutan dengan pencapaian jumlah skor sebanyak 4,3, pencapaian pada parameter ini tergolong kategori sangat baik. Berikut data hasil program lumbung pangan yang dirincikan pada Tabel 3.

Tabel 3.

Hasil program lumbung pangan masyarakat di Kecamatan Kerambitan, Tahun 2016

\begin{tabular}{lcc}
\hline \multicolumn{3}{c}{ Hasil program Lumbung Pangan Masyarakat } \\
\hline \multicolumn{1}{c}{ Parameter } & Skor Rata-rata & Kategori \\
\hline $\begin{array}{l}\text { Tersedianya cadangan pangan kelompok } \\
\text { Berkembangnya cadangan pangan kelompok }\end{array}$ & 3,7 & Baik \\
$\begin{array}{l}\text { secara berkelanjutan } \\
\text { Meningkatnya kemampuan kelompok } \\
\text { mengelola lumbung pangan }\end{array}$ & 4,3 & Sangat baik \\
$\begin{array}{l}\text { Kelompok mampu menyusun laporan } \\
\text { pertanggung jawaban program }\end{array}$ & 4 & Baik \\
\hline \multicolumn{1}{c}{ Jumlah } & 3,8 & Baik \\
\hline
\end{tabular}

Berdasarkan Tabel 3. Hasil wawancara pencapaian dengan kategori sangat baik diperoleh karena cadangan pangan yang dikumpulkan para anggota setiap panen terus meningkat. Para anggota memiliki pendapat jika hasil panen yang sudah didapat tidak bagus jika disimpan terlalu lama karena takut jika hasil panen yang disimpan terlalu lama akan merusak kualitas hasil panen. Persentase pencapaian skor terendah terjadi pada parameter tersedianya cadangan pangan kelompok dengan jumlah skor rata - rata 3,7, yang tergolong dalam kategori baik. 
Hal ini berkaitan dengan pernyataan para anggota kelompok yang beranggapan jika menyimpan hasil panen terlalu lama maka kualitas hasil panen yang akan dijual akan menjadi rendah. Jika hasil panen disimpan terlalu lama maka gabah yang dipanen dapat menjadi lapuk dengan sendirinya. Pada parameter meningkatnya kemampuan kelompok mengelola lumbung pangan mencapai skor rata-rata 4 dengan kategori baik. Kategori yang diberikan baik, karena para anggota mau bersma-sama mengelola lumbung pangan dengan baik dan para pengurus memberikan informasi keuangan kelompok secara transparan, sehingga terciptanya rasa saling percaya terhadap sesama anggota dalam mengurus dan mengembangkan kelembagaan lumbung pagan.

Hasil program dalam parameter kelompok mampu menyusun laporan pertanggung jawaban tergolong pada kategori baik dengan skor 3,8. Kategori baik diperoleh karena para pengurus kelompok melakukan kegiatan penyusunan laporan pertanggung jawaban program disela-sela waktu rapat selesai masa panen yang dimana para pengurus beranggapan bahwa waktu tersebut merupakan waktu yang efektif untuk menyelesaikan laporan-laporan yang diperlukan untuk pelaporan kepada dinas terkait.

\section{Simpulan dan Saran}

\subsection{Simpulan}

Berdasarkan hasil penelitian penerapan dan hasil dari evaluasi penerapan program lumbung pangan masyarakat pada kelompok lumbung pangan masyarakat di Subak Seronggo dapat disimpulkan sebagai berikut.

1. Penerapan program lumbung pangan masyarakat di Subak Seronggo dilihat dari tahap penumbuhan termasuk baik karena program yang dibentuk pemerintah memiliki tujuan yaitu: meningkatkan volume stok cadangan pangan di kelompok lumbung pangan, meningkatkan kemampuan pengurus dan anggota kelompok dalam pengelolaan cadangan pangan, meningkatkan fungsi kelembagaan cadangan pangan dalam penyediaan pangan secara optimal dan berkelanjutan. Tahap pengembangan secara keseluruhan masuk kategori baik karena para anggota kelompok mampu menjalankan dan menerapkan prosedur kegiatan kelompok lumbung pangan yang telah ditetapkan oleh dinas ketahanan pangan Kabupaten Tabanan. Dilihat dari tahap kemandirian secara umum masuk kategori sedang karena para anggota kelompok lumbung pangan memberikan penilaian sangat beragam pada parameter tahap kemandirian.

2. Hasil program lumbung pangan di Subak Seronggo secara umum masuk kategori baik karena para anggota mengelola dan memanfaatkan bantuan dengan perjanjian yang dibentuk sesuai kesepakatan kelompok sehingga kesenjangan sosial di dalam kelompok tidak terjadi. 


\subsection{Saran}

Saran yang dapat dikemukakan berdasarkan hasil penelitian ini sebagai berikut.

1. Pemerintah sebaiknya dalam proses sosialisasi dan pelatihan yang diberikan agar lebih menentukan standar yang baik bagi narasumber yang akan menjelaskan materi sosialisasi sehingga petani mudah memahami materi yang disampaikan.

2. Kelompok lumbung pagan di Subak Seronggo sebaiknya meminta kepada pemerintah untuk memberikan pelatihan tambahan dan pendampingan yang intensif sebelum para anggota menjadi anggota kelompok lumbung pangan yang mandiri.

3. Kelompok lumbung pangan sebaiknya saling berkoordinasi dengan kelompok lumbung pangan yang lainnya agar kelompok mendapatkan ilmu tambahan dalam mengembangkan kelembagaan dan cadangan kelompok lumbung pangan masyarakat.

\subsection{Ucapan Terimakasih}

Terimakasih kepada PPL, pekaseh dan petani Subak Seronggo yang telah memberikan data dalam penyelesaian penelitian dan penulisan e-journal ini. Semoga penelitian ini dapat bermanfaat sebagaimana mestinya.

\section{Daftar Pustaka}

Bustanul Arifin, 2005. Pengertian Ketahanan Pangan. http://www.budidayapetani.com Diakses pada: 25 Maret 2016.

Dajan, Anto. 1978. Pengantar Metode Statistik. Jilid II. Jakarta : LP3ES.

Jayawinata, Ardi. 2015. Pemberdayaan Lumbung Pangan. Tersedia :https://ppljatinangor.wordpress.com. Diakses pada: Agustus 2015

Juklak BPMPD. 2014. Pengembangan Lumbung Pangan Masyarakat Provinsi Bali. Bali : BPMPD.

Revikasari. 2010. Peranan Penyuluh Pertanian dalam Pengembangan Gabungan Kelompok Tani (GAPOKTAN) di Desa Tempuran Kec. Paron Kab. Ngawi. https://core.ac.uk/download/pdf/12349246.pdf. Diunduh pada tanggal 8 agustus 2016

Sevilla, Consuelo et, Al. 1993. Pengantar Metode Penelitian. Jakarta : Universitas Indonesia Press.

Singarimbun, M dan S. Effendi. 1998. Metode Penelitian Survei. Jakarta : LP3ES.

Sugiyono. 2010. Metode Penelitian Pendidikan: Pendekatan Kuantitatif, Kualitatif dan $R \& D$. Bandung : Alfabeta.

Surakhmad, W. 1994. Pengantar Penelitian Ilmiah. Dasar, Metode dan Teknik. Bandung : Tarsito.

Wibisono, Dermawan. 2013. Panduan Penyusunan Skripsi, Tesis dan Disertasi. Yogyakarta : Andi. 